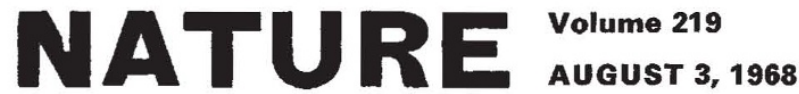

\section{What the Pope Expects}

Nature has no natural interest in religious matters, which is another way of saying that readers do not look to it for information about theology and related subjects. Papal encyclicals are not usually reviewed, and there is much in what the Pope had to say in Rome on Tuesday this week which is entirely outside those fields in which scientists, as scientists, can reasonably hope to exercise their natural curiosity. It is, however, a fact that one part of the encyclical is addressed "To men of science", and there is no doubt that the practical consequences of what the Pope has said could turn out to be extremely serious and in conflict with the aspirations if not the achievements of a good deal of scientific endeavour in recent years. Although some have compared the Pope's proscription of contraception with the trouble about Galileo 350 years ago, that parallel is not particularly convincing, but there is no question that this pronouncement could easily turn out to be a powerful brake on the steady process of improvement which has now begun in less fortunate parts of the world. Everything will depend on how much weight the encyclical will carry.

The essence of the Pope's position is that of his predecessors going back to 1930 , when the traditional position of the Catholic Church was spelled out by Pope Pius XI - at a time of shrinking populations in Europe and elsewhere. Briefly, there is a distinction between the exploitation for the purposes of infecundity of the infertile periods between menstrual cycles and the use of chemical or other artefacts. Infecundity by natural methods is permissible, but everything else is bad. The exhortation to scientists in the encyclical takes the form of a plea for research into "the various conditions favouring a proper regulation of births", so as to "contribute to demonstrate in actual fact" the doctrine that "a true contradiction cannot exist between the divine laws pertaining to the transmission of life and those pertaining to the fostering of authentic conjugal love".

The trouble here, in part, is the difference between a theoretical and a practical solution. Undoubtedly a more refined understanding of the process of ovulation will be obtained in the course of time--and there will be better ways of detecting the onset of ovulation than the bedside thermometer. But the problem with the natural rhythm method of contraception is that it does not work well or easily among less favoured populations. And for all the opposition to the Pope's encyclical which has sprung up in the past few days, from Catholics and others, the chances are that populations in prosperous countries will be much less seriously hampered by the new edict than those less able to speak up for themselves.
This is where the Pope's doctrine is thinnest. He acknowledges that some countries have demographic problems, but asks that governments should deal with them by "a provident policy for the family . . . a wise education of peoples in respect of the moral law and the liberty of citizens". It is fair to acknowledge that the threat of sheer starvation has long since been displaced from the head of the list of demographic troubles by the fear that the pressure of population on an impoverished community may keep whole populations in thrall in a kind of poverty unknown among industrialized societies since the beginning of the industrial revolution. In circumstances like these, provident policies for families are already acknowledged to be necessary--which does not mean that they are easily designed or implemented. In several countries-those in South America, for example--the promise of comparatively simple contraception has recently seemed one way in which the vicious eycle of poverty and population might be broken. The fact that agriculture in some developing countries is at last showing real signs of progress can hardly be held to be a compelling argument. Most probably, the problem will only be solved if population growth can be stemmed at the same time as food production is increased.

What is now to be done? The most immediate danger is that the new encyclical may impede the liberal attempts which have been or are being mounted by all kinds of organizations to make birth control more easily usable in several of the countries which need it most. Reports of the incidence of abortion in some places (see page 428) are by themselves a vivid indicator of how much there is to do. No doubt it will now be harder for those governments which would like more liberal legislation on birth control to get more liberal rules adopted. International and private agencies will at the same time find it harder to win the open support of many governments in countries where there is a need of help. In the circumstances, it is hard to know what can be done. It would, of course, be folly to expect that the hard line on contraceptives will soon be relaxed, though it is not unreasonable to hope that governments will be able to make a resolute response to it. It is of course quite proper that Catholics should do as they wish, or even as they are told, but governments must surely take steps to safeguard the rights of non-Catholics even when these are a minority. That, at least, is the best hope of taking the sting out of a pronouncement which seems unnecessary, which is certainly needlessly harsh in tone and which will otherwise be remembered as an exceedingly illiberal development. 